\title{
Sterigmatomyces acheniorum species nova, a Yeast from Strawberries
}

\author{
By R. W. M. BUHAGIAR \\ Agricultural Research Council Food Research Institute, \\ Colney Lane, Norwich, NOR $70 F$ \\ AND J. A. BAR NETT \\ School of Biological Sciences, University of East Anglia, Norwich \\ (Received 3I January 1973) \\ SUMMARY

\begin{abstract}
A new species of yeast, Sterigmatomices acheniorum, is described. The strains, isolated from fresh strawberries, differed from other species of Sterigmatomyces in the test substrates they utilized. The strains grew slowly on certain organic substrates on three of which they formed mainly small colonies with a minority of large ones. When subcultured on the same substrates, large colonies gave rise to further large colonies, and small colonies produced mainly small colonies with a minority of large ones.
\end{abstract}

\section{INTRODUCTION}

During a recent survey of yeasts associated with fresh strawberries (Buhagiar \& Barnett, 1971), a strain of a kind hitherto undescribed was isolated in 1969; a further five similar strains were isolated in 1970 and another in 1971 . Four were isolated at $15 \mathrm{C}$ and the others at $20^{\circ} \mathrm{C}$ and $25^{\circ} \mathrm{C}$, all from surface colonies on Difco Bacto YM agar at pH 3.4 or $4 \cdot 8$. The present paper describes the new species.

\section{MITHODS}

The methods used have been described by Barnett \& Buhagiar (1971) and Buhagiar \& Barnett (1971).

\section{Macroscopical appearance}

RI:SULTS

Streak cultures on Difco Bacto YM agar at $25{ }^{\circ} \mathrm{C}$ were creamy white and semiglossy after 2 or 3 days; cream to buff coloured with well defined margins, flat, matt or semiglossy after one week; cream or buff, matt, granular, with pale striated margins and well defined lobate edges after one month. Cultures may be pink on some samples of malt extract agar (D. Yarrow, 1972, personal communication).

\section{Microscopical appearance}

In exponential growth, the cells were ellipsoidal, elongate or pear-shaped and measured $4.4 \times 2.7 \mu \mathrm{m}$ (mean of 382 cells of five strains; mode $4.2 \times 2.6 \mu \mathrm{m}$; maxima $7.9 \times 4.0 \mu \mathrm{m}$; minima $2.6 \times \mathrm{I} \cdot 6 \mu \mathrm{m}$; see Table I). Length and breadth were not highly correlated. Buds were usually formed on sterigmata, of which each cell put out one, two or three simultaneously. After reaching about I $\mu \mathrm{m}$ in length, each sterigma formed a distal, spherical swelling which was a new bud (cf. Fell, 1970; see Fig. I). Each bud enlarged and lengthened, 


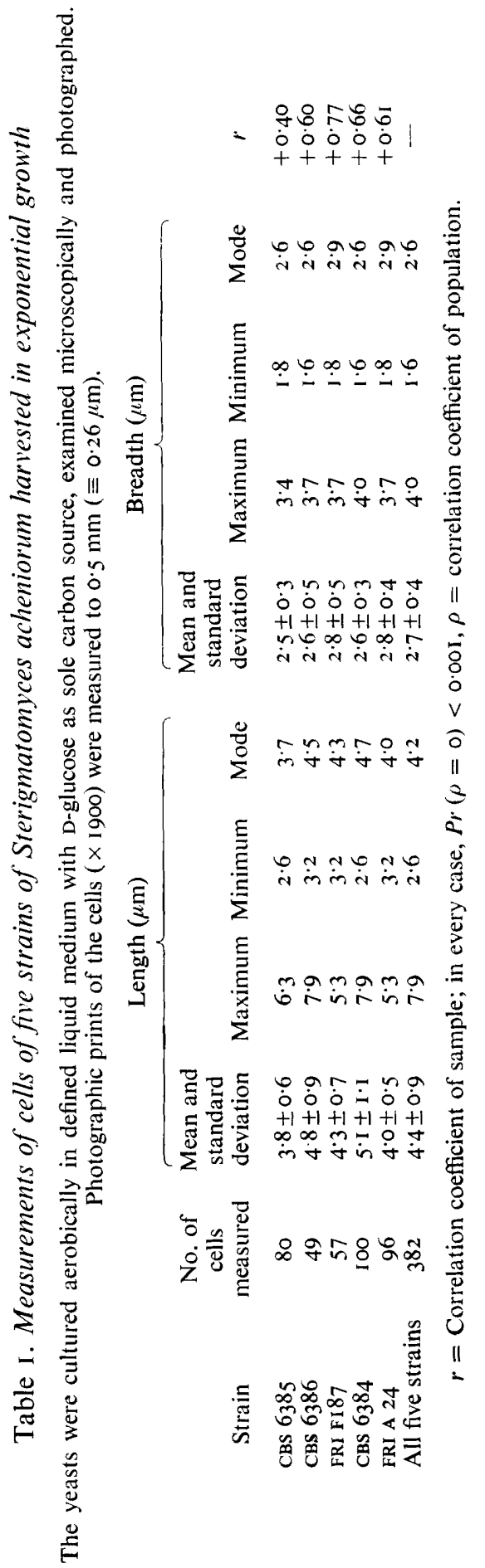


becoming about the same size as the mother-cell from which it then separated. When daughter- and mother-cells separated, the linking sterigmata appeared to break either at the mother-cell or at the daughter-cell or midway between. Occasionally sterigmata did not break and chains of up to four cells were formed, each cell separated from the next by a short sterigma. Most sterigmata were apical or nearly apical; the older ones were thicker, and some were curved, appearing flexible; the buds were seen to move relative to the mothercell though still fully attached. Each strain produced a number of cells with lateral sterigmata. Half-way along some sterigmata, a swelling occurred from which one or two buds formed. Cells growing in defined media were similar to those in Difco Bacto malt extract (Fig. 2).

There was poor growth under the coverslips in slide cultures; a little primitive pseudomycelium occurred outside the coverslips. No ascospores or ballistospores were formed.

\section{Physiological tests}

Semi-anaerobic fermentation. The yeasts did not produce gas in Durham tubes from yeast water with 50 mM-D-glucose.

Aerobic growth tests gave the results shown in Table 2. Growth on ten substrates was delayed or slow when compared to growth on glucose. Fig. 3 shows the growth of one strain on nine of these substrates, namely methyl $\alpha$-D-glucoside, cellobiose, melibiose, lactose, L-sorbose, D-arabinose, ribitol, D-glucose or inulin.

Other tests. Starch production tests gave negative results; urea was hydrolysed. All strains grew best at about $20^{\circ} \mathrm{C}$; at $30^{\circ} \mathrm{C}$ five strains grew poorly and one (A24) not at all. None grew at $37^{\circ} \mathrm{C}$. No evidence for acid production was seen after one week on $\mathrm{CaCO}_{3}$ plates.

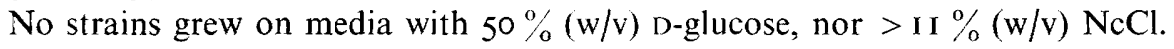

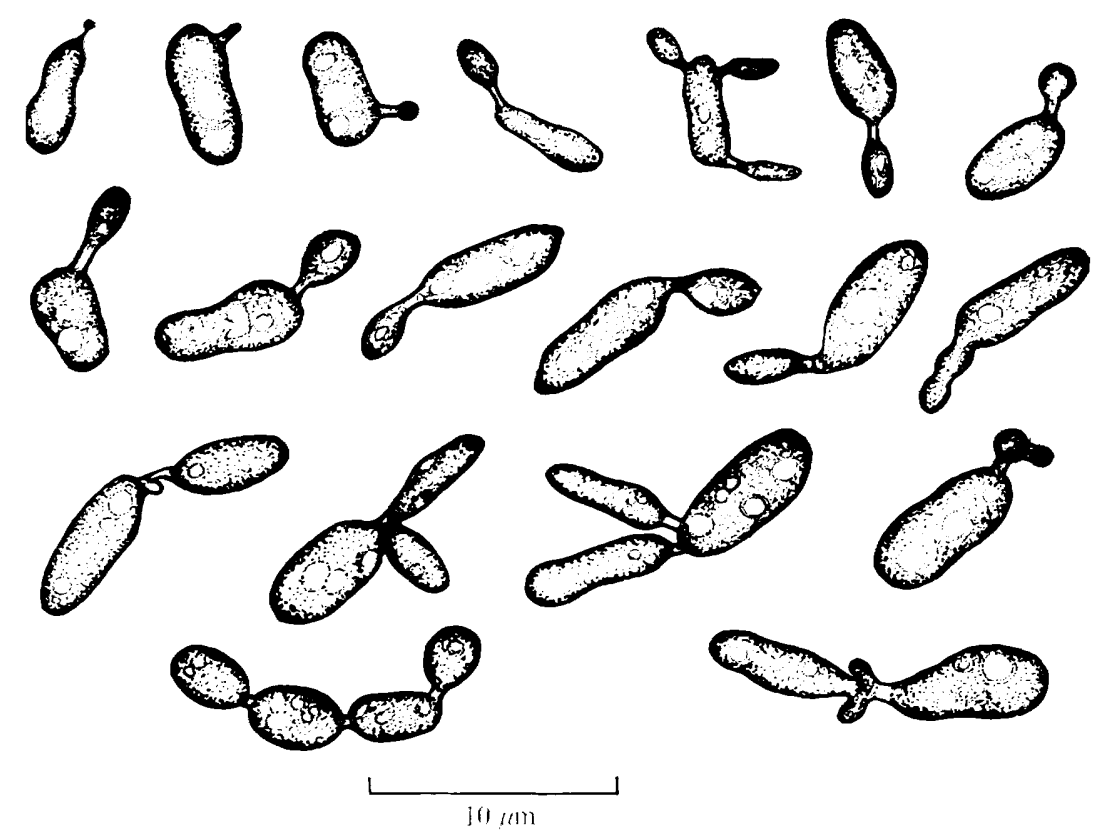

Fig. I. Drawing of Sterigmatomyces acheniorum during exponential growth in shaken culture of defined liquid medium with $\mathrm{D}$-glucose as sole source of carbon. The drawing was made from photomicrographs of several strains, to illustrate the various forms. 


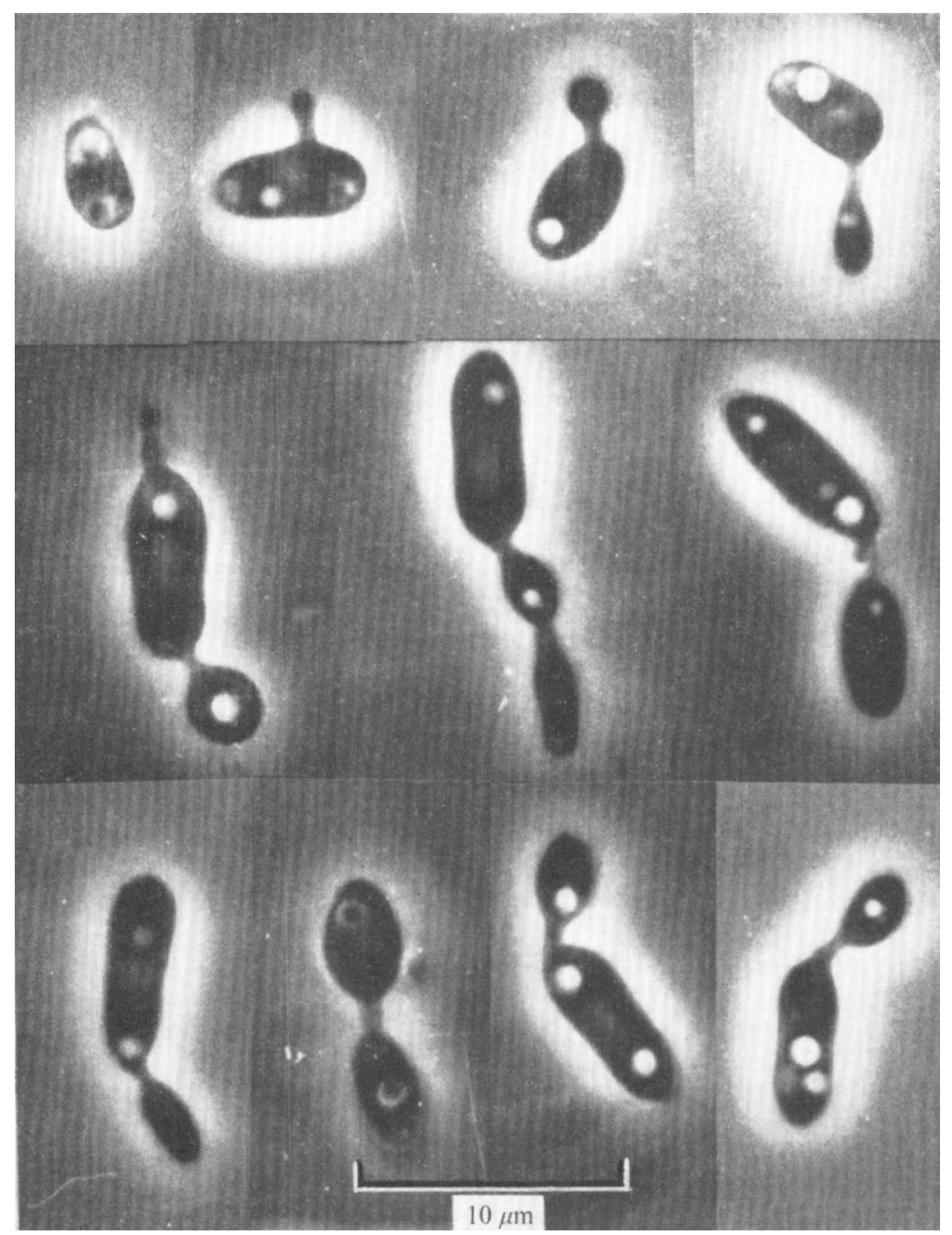

Fig. 2. Photomicrograph of Sterigmatomyces acheniorum (CBS 6384) growing aerobically in unshaken Difco Bacto malt extract for 3 days at $25^{\circ} \mathrm{C}$. Leitz phase contrast (Heine).

Slow growths

* Since various interpretations can be given to delayed responses in growth tests (Knight, 1938; Barnett, 1966, I968a), the slow growth of three strains of Sterigmatomyces acheniorum on methyl $\alpha$-D-glucoside, on melibiose and on lactose was examined further.

It was necessary to ensure that the late growths were not a consequence of changes in the media resulting from long incubation. Three lots of uninoculated complete medium, each including methyl $\alpha$-D-glucoside, melibiose or lactose (all filter-sterilized as usual), were therefore incubated at $25^{\circ} \mathrm{C}$ for three months. Growth in such pre-incubated medium was not markedly different from that in fresh medium, and hence non-enzymatic hydrolysis of the glycosides was probably not significant. The growth rate on any substrate was not affected appreciably when the inoculum had been grown on that substrate rather than on glucose. Hence we investigated the possibility that the slow growths could be explained in terms of selection. After plating serial dilutions of each strain on agar medium containing one or 


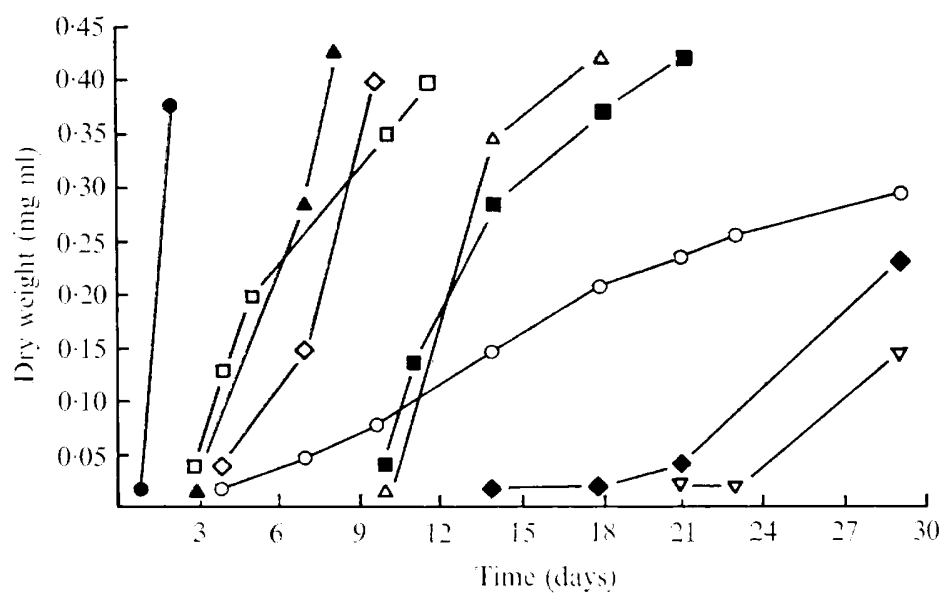

Fig. 3. Growth of Sterigmatomyces achenionum (CBS 6386) on nine test compounds. Test tubes contained initially $5 \mathrm{ml}$ of the chemically defined liquid basal medium (Barnett \& Ingram, 1955), $250 \mu$ mole of substrate (as indicated), inoculated with about $5 / \mathrm{g}$ dry wt of yeast from a slope of Difco Bacto YM agar incubated at $15 \mathrm{C}$ for 3 days. The tubes were incubated at $20 \mathrm{C}$ and were rocked through an angle of about 40 to 15 from the horizontal. Each point on the graph corresponds to a single nephelometric observation. - D-glucose; ᄀ, methyl $\alpha$-D-glucoside; $\Delta$, melibiose; $\curvearrowright$ D-arabinose; $O$, inulin; $\mathbf{\square}$, cellobiose; $\Delta$, lactose; $\triangleleft$, ribitol; $\nabla$, L-sorbose.

\section{Table 2. Results of aerobic grow'th tests on Sterigmatomyces acheniortum}

\begin{tabular}{|c|c|c|c|c|c|}
\hline Substrate & Response & Substrate & Response & Substrate & Response \\
\hline Raffinose & + & D-Glucose & + & Glycerol & S \\
\hline Melezitose & + & D-Galactose & $\div$ & Erythritol & + \\
\hline Sucrose & + & L-Sorbose & S & Ribitol & $\mathbf{S}$ \\
\hline Maltose & + & L-Rhamnose & - & D-Glucitol & + \\
\hline Trehalose & + & & & D-Mannitol & + \\
\hline Methyl $x$-D-glucoside & $\mathrm{S}$ & $\begin{array}{l}\text { D-Ribose } \\
\text { D-Xylose }\end{array}$ & + & Galactitol & - \\
\hline Cellobiose & $\mathrm{S}$ & D-Arabinose & $\mathrm{S}$ & $m y o$-Inositol & -_ \\
\hline Salicin & - & L-Arabinose & + & & \\
\hline Melibiose & $\mathrm{S}$ & $\begin{array}{l}\text { Succinate } \\
\text { Citrate }\end{array}$ & + & $\begin{array}{l}\text { Starch } \\
\text { Inulin }\end{array}$ & $\overline{\mathrm{S}}$ \\
\hline Lactose & $\mathrm{S}$ & Lactate & $\mathrm{S}$ & Nitrate & + \\
\hline \multirow{2}{*}{\multicolumn{3}{|c|}{$\begin{array}{l}\text { D-glucose (medium without vitamins) } \\
\text { YM agar }+50 \%(\mathrm{w} / \mathrm{v}) \text { D-glucose }\end{array}$}} & - & YM agar at 30 & C very little growth \\
\hline & & & - & YM agar at 37 & $\mathrm{C}-$ \\
\hline
\end{tabular}

+ , Growth reached about $0.4 \mathrm{mg}$ dry wt/ml within 7 days; - , no growth; $\mathrm{S}$, growth did not reach $0.4 \mathrm{mg}$ dry wt $/ \mathrm{ml}$ until after 7 days, with an initial delay of at least 3 days (cf. Barnett \& Buhagiar, I97I; Buhagiar \& Barnett, 1971).

other of the glycosides or D-glucose (Barnett, $1968 \mathrm{~b}$ ), there were no appreciable differences between substrates in numbers of colonies for any one strain. However, although the colonies on medium containing $50 \mathrm{mM}-\mathrm{D}$-glucose as sole carbon source appeared uniform, those on $50 \mathrm{~mm}$ methyl $\alpha$-D-glucoside, melibiose or lactose were mixed, mainly small, with not more than about $10 \%$ large. After 9 days at $20{ }^{\circ} \mathrm{C}$ with methyl $\alpha$-D-glucoside the 'large' colonies were about $3 \mathrm{~mm}$ diam. and the 'small' colonies I mm diam. (Fig. 4, 5). There were no obvious differences in the size of cells from the two kinds of colony. 


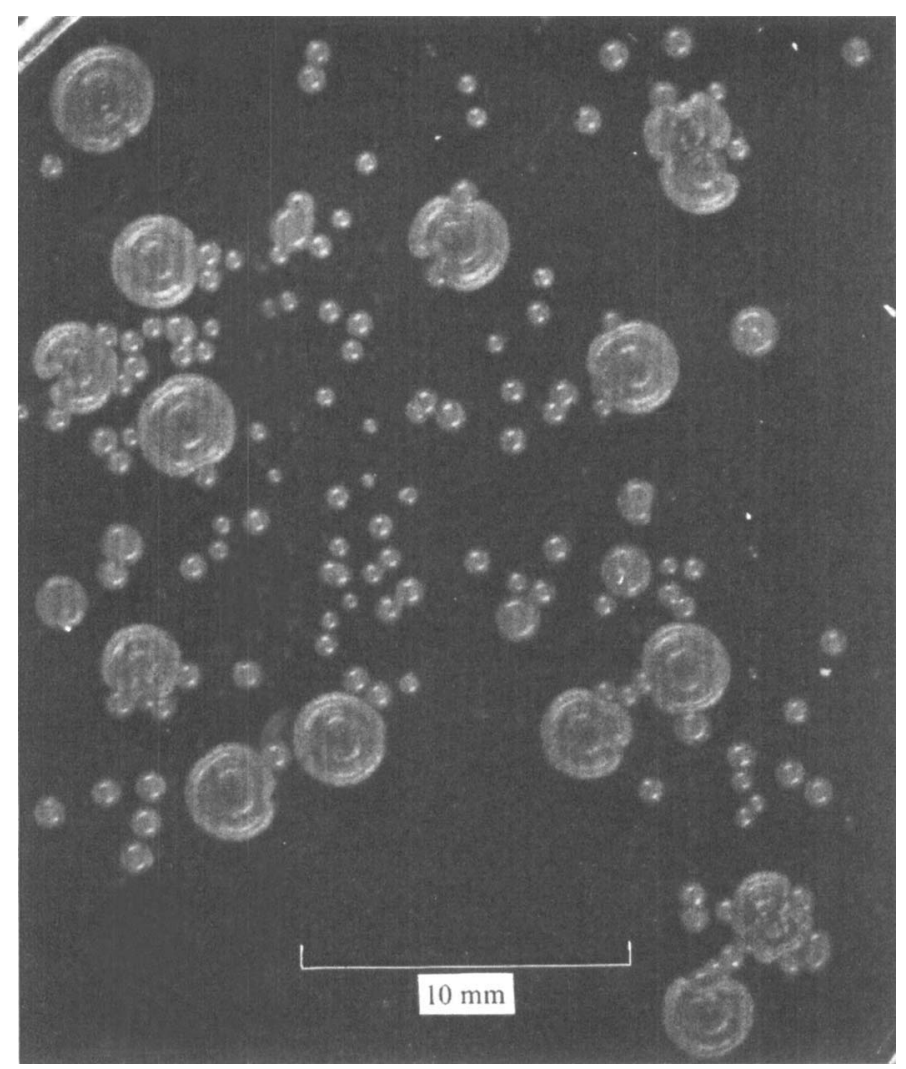

Fig. 4. Photograph showing large and small colonies of Sterigmatomyces acheniorum (CBS 6386) on defined medium with $50 \mathrm{~mm}$-methyl $\alpha$-D-glucoside as sole source of carbon after 9 days of incubation at $20^{\circ} \mathrm{C}$. The inoculum was grown on Difco Bacto YM agar.

Colonies of both sizes were picked off, subcultured several times on YM agar and then replated successively on each glycoside. Considering any pair of glycosides, A and B, large colonies from A gave rise to large colonies on A, and mainly small colonies on B. Small colonies from A gave mainly small colonies on either A or B. For example, with strain CBS 6386 on methyl $\alpha$-D-glucoside, colonies derived from an originally small colony included a minority that were large. Those derived from a large colony were all large. At the second plating, colonies generally tended to be smaller than those from which they originated. Cultures derived from a small colony on a given substrate and grown aerobically on that substrate in agitated liquid medium had a longer lag than did those cultures derived from large colonies (Fig. 6). There was no marked difference in the maximum growth rates.

When the concentration of glycoside was varied between $25 \mathrm{~mm}$ and $300 \mathrm{~mm}$, the size distributions of the colonies, plated directly from the original stock cultures, showed differences comparable to those described above, though the colonies were larger when grown on higher concentrations of substrate. 


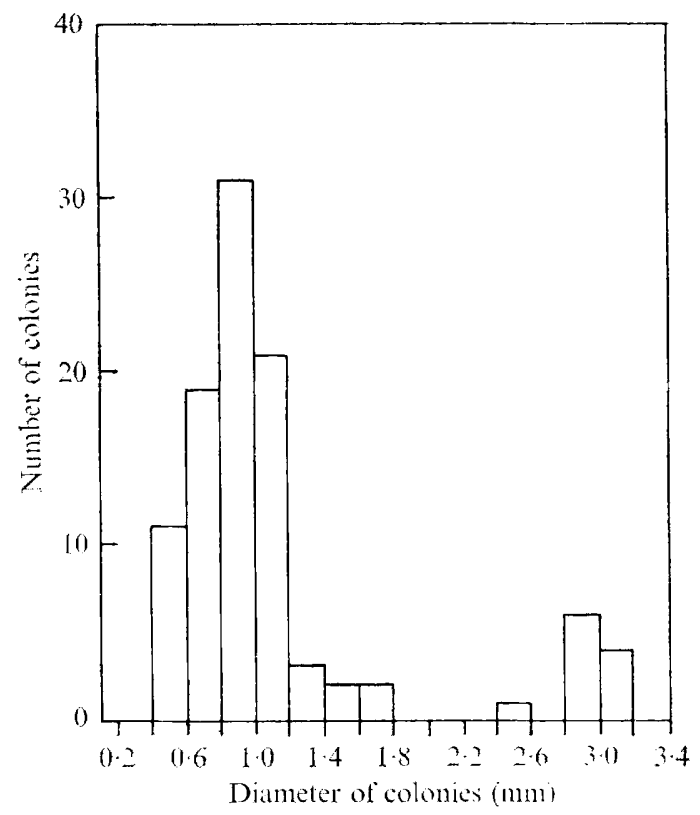

Fig. 5

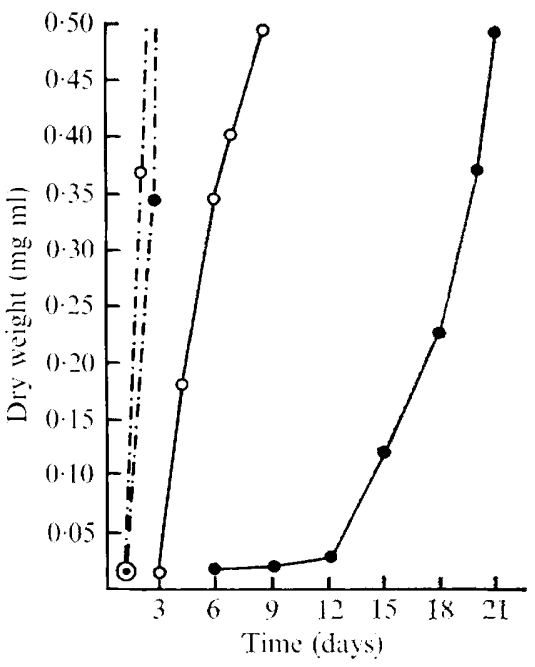

Fig. 6

Fig. 5. Histogram showing distribution of size of 100 colonies of Sterigmatomyces acheniorum (CBS 6386) growing on methyl $\alpha$-D-glucoside as sole source of carbon with conditions as for Fig. 4.

Fig. 6. Growth of Sterigmatomyces acheniorum (CBs 6385) on 50 mM-methyl $\alpha$-D-glucoside (- - ), or D-glucose (-.-.--), for a subculture derived from $\bigcirc$, a large colony; and for $\bullet$, a small colony (see text). Conditions were as for Fig. 3.

\section{DISCUSSION}

The strains of yeast described here did not appear to form ascospores, were non-filamentous and produced daughter-cells on sterigmata. Together, these three features are characteristic of Sterigmatomyces Fell (Fell, 1970) and of no other genus of yeast (Lodder, 1970). Had the colonies been notably pink from carotenoid pigment, these yeasts might have been considered as Rhodotorulae, though budding on sterigmata is not a feature of that genus (Phaff \& Ahearn, I970). Verona \& Rambelli (I962) described features of some species of Taphrina that are common to Sterigmatomyces acheniorum, notably the sterigmata. However, unlike the latter, Taphrina species do not utilize either lactose or erythritol (Mix, 1954). Furthermore, they form starch which, according to Lodder (I970), is taxonomically critical in the present context.

Among the existing species of Sterigmatomyces, Sterigmatomyces acheniorum most closely resembled the description of $S$. halophilus, but differed markedly from the latter in utilizing readily sucrose, maltose, raffinose, melezitose and also in being non-halophilic. Because of these differences, we gave our strains a new specific name, 'acheniorum', as they were associated with the achenes and receptacle of Fragaria ananassa.

The slow growth on certain glycosides was examined as a special feature of the species. However, some incidental observations on other yeasts suggest that our findings may well apply quite widely in the yeasts and be of general interest. The repeated occurrence of such large and small colonies as those shown in Fig. 4 must have been interpreted from time to time in terms of mixed cultures in the sense of their not having been derived from a 
single-cell isolation. Particular care was taken in purifying our strains to avoid such a mistake, though no physiological explanation is offered of our observations on the sizes of the colonies.

Three strains of Sterigmatomyces acheniorum have been deposited in the collection of the Centraalbureau voor Schimmelcultures, Delft; no. 6386 is the type strain.

\section{Sterigmatomyces acheniorum species nova}

In liquore definito cum D-glucoso, in augendo ad $25^{\circ} \mathrm{C}$, cellulae sunt in forma aut ellipses aut piri, 2.6 ad $7.9 \times$ I.6 ad $4.0 \mu \mathrm{m}$. Gemmae e sterigmatibus (circa I $\mu \mathrm{m}$ longorum) fere faciunt. Ascosporae, ballistosporae, hyphae, pseudohyphaeque non sunt. Non est fermentatio. Fermenta speciei huius crescunt in liquore definito cum raffinoso, melezitoso, sucroso, maltoso, trehaloso, methyl $\alpha$-D-glucosido (lente), cellobioso (lente), melibioso (lente), lactoso (lente), D-glucoso, $\mathrm{D}-$ galactoso, L-sorboso (lente), D-riboso, D-xyloso, D-arabinoso (lente), L-arabinoso, succinato, citrato, lactato (lente), glycerolo (lente), erythritolo, ribitolo (lente), D-glucitolo, D-mannitolo, inulino (lente), nitrato. Non crescunt cum salicino, L-rhamnoso, galactitolo, myo-inositolo, amylo. Vitaminas addere necessarium est. In $37^{\circ} \mathrm{C}$ non crescunt; in $30^{\circ} \mathrm{C}$ lente crescunt. In $50 \%$ D-glucoso non crescunt. Amylum non formant. Urea hydrolysantur.

Typus cultura 6386 in collectione Centraalbureau voor Schimmelcultures, Delft, isolata e fragoribus.

We thank Mr M. J. Brown for expert photographic help and Dr D. Yarrow of the Centraalbureau voor Schimmelcultures for examining three strains and confirming our opinion on their identity.

\section{REFERENCES}

BARnett, J. A. (1966). Biochemical differences between yeasts. Journal of General Microbiology 42, i-ii.

BARnetT, J. A. (1968a). Biochemical differentiation of taxa with special reference to the yeasts. In The Fungi, vol. III, pp. 557-595. Edited by G. C. Ainsworth and A. S. Sussman. London: Academic Press.

BARnetT, J. A. (1968b). The catabolism of acyclic polyols by yeasts. Journal of General Microbiology $\mathbf{5 2}^{2}$, I3I-I59.

Barnett, J. A. \& Buhagiar, R. W. M. (1971). Torulopsis fragaria species nova, a yeast from fruit. Journal of General Microbiology 67, 233-238.

Barnett, J. A. \& Ingram, M. (1955). Technique in the study of yeast assimilation reactions. Journal of Applied Bacteriology I8, 13 I-I 48.

Buhagiar, R. W. M. \& Barnett, J. A. (I971). The yeasts of strawberries. Journal of Applied Bacteriology 34, 727-739.

Fell, J. W. (1970). Sterigmatomyces Fell. In The Yeasts. A Taxonomic Study, pp. 1229-34. Edited by J. Lodder. Amsterdam: North-Holland Publishing Co.

KNIGHT, B. C. J. G. (1938). Bacterial Nutrition. Medical Research Council Special Report no. 2 Io. London: His Majesty's Stationery Office.

Lodder, J. (I970). The Yeasts. A Taxonomic Study. Amsterdam: North-Holland Publishing Co.

Mix, A. J. (1954). Differentiation of species of Taphrina in culture. Utilization of carbon compounds. Mycologia 46, 72I-727.

Phaff, H. J. \& Ahearn, D. G. (I970). Rhodotorula Harrison. In The Yeasts. A Taxonomic Study, pp I I87-I223. Edited by J. Lodder. Amsterdam: North Holland Publishing Co.

Verona, O. \& RAmbelli, A. (I962). Notizie intoruo ai carratteri di alcune specie di Taphrina in fase Saprofitaria (Saprotaphrina). Annali della Facoltà di Agraria della Universita di Pisa 23, I-36. 